Relations industrielles

Industrial Relations

\title{
La Recherche sur les relations industrielles au Canada- Industrial Relations Research in Canada, 1973, Ottawa, Travail Canada, 1974, 193 pp.
}

\section{Gérard Dion}

Volume 29, numéro 3, 1974

URI : https://id.erudit.org/iderudit/028544ar

DOI : https://doi.org/10.7202/028544ar

Aller au sommaire du numéro

\section{Éditeur(s)}

Département des relations industrielles de l'Université Laval

\section{ISSN}

0034-379X (imprimé)

1703-8138 (numérique)

Découvrir la revue

Citer ce compte rendu

Dion, G. (1974). Compte rendu de [La Recherche sur les relations industrielles au Canada - Industrial Relations Research in Canada, 1973, Ottawa, Travail Canada, 1974, 193 pp.] Relations industrielles / Industrial Relations, 29(3), 625-625. https://doi.org/10.7202/028544ar

Tous droits réservés @ Département des relations industrielles de l'Université Laval, 1974
Ce document est protégé par la loi sur le droit d'auteur. L'utilisation des services d’Érudit (y compris la reproduction) est assujettie à sa politique d'utilisation que vous pouvez consulter en ligne.

https://apropos.erudit.org/fr/usagers/politique-dutilisation/ 
such issues in any depth in a brief review. Three points, however, may be made as reasonable assertions.

(1) There are great opportunities, as well as adjustment problems, for the advanced countries in the emerging industrial markets of developing nations. If the adjustment problems are not tackled firmly and well, individual advanced countries may find themselves later at a disadvantage arising from a structure of manufacturing output which is not appropriate to world competitive conditions.

(2) Since adjustment problems are large when viewed in a long-range perspective, there is a case for early and continuing measures to promote adjustment, in order to avoid sudden and disruptive change at some future time.

(3) The smooth integration of developing countries into an open world economy can only occur as a result of a joint (or at least co-ordinated) effort by the industrial country group.

Since the seminar was held, the energy cost crisis has become more acute and has affected developed and developing countries in disparate ways. This development has certainly complicated the already difficult problems of raising the standard of living of third world countries, with its sudden and large redistribution of current world incomes. It has not, however, eliminated the need to increase world incomes in ways that will contribute positively to an acceptable level and distribution in future.

\section{J. R. DOWNS}

\section{Economic Council of Canada} Ottawa

\section{Current Perspectives in Organization} Development, par J. Jennings Partin, (Ed.), Mass., Addison-Wesley $\mathbf{P u}$ blishing Co., 1973, 279 pp.

Cet ouvrage est un recueil d'expériences vécues dans le domaine du développement des organisations. Jusqu'à maintenant, nous disposons d'une gamme d'ouvrages et d'articles académiques sur le sujet où il est possible de trouver quelques expériences éparses, relatées de façon assez sommaire. Ce volume nous apporte une description assez dé- taillée de treize organisations qui ont tenté divers efforts de changernent planifié. Chaque expérience est décrite par une personne qui a été impliquée dans l'effort de développement en prenant soin de bien présenter la méthodologie utilisée et les techniques de sensibilisation, de diagnostic, de planification des activités de changement, etc.

De plus, une courte évaluation de chaque expérience donne une bonne idée des résultats obtenus, des difficultés rencontrées et des limites de diverses stratégies de changement. Ce qui m'a impressionné le plus dans cet ouvrage, c'est la diversité des stratégies et des techniques utilisées tant au plan du démarrage des expériences, de leur déroulement et de leur évaluation. Pour mieux saisir la signification de chaque expérience, il faut au point de départ lire la synthèse préparée par l'éditeur sur la notion de développement organisationnel, les phases du processus, les stratégies et les techniques les plus utilisées, de même que la nomenclature des habiletés exigées d'un agent de changement dans ce domaine.

Laurent BELANGER

Université Laval

La Recherche sur les relations industrielles au Canada - Industrial Relations Research in Canada 1973, Ottawa, Travail Canada, 1974, 193 pp.

Cet ouvrage est un répertoire établi et publié par la Direction de l'économique et des recherches du ministère du Travail du Canada. Il présente une liste des travaux de recherches sur les relations industrielles entrepris par le ministère, d'autres ministères du gouvernement, des maisons d'enseignement et des particuliers. L'enquête sur laquelle se fonde ce répertoire a été menée à la fin de 1973. On y trouve la liste, de 436 travaux en marche avec le stade auquel ils sont rendus ainsi que le nom et l'adresse des auteurs. En publiant ce répertoire annuel, qui est le sixième, le ministère du Travail rend un grand service à tous les chercheurs. Nous nous réjouissons du progrès accompli, car cette année, la publication s'est faite dans des délais raisonnables.

Université Laval
Gérard DION 